\title{
Nyctiphanes couchii as intermediate host for the acanthocephalan Bolbosoma balaenae in temperate waters of the NE Atlantic
}

\author{
M. Gregori' ${ }^{1, *}$, F. J. Aznar ${ }^{2}$, E. Abollo ${ }^{3}$, Á. Roura ${ }^{1}$, Á. F. González ${ }^{1}$, S. Pascual ${ }^{1}$ \\ ${ }^{1}$ Instituto de Investigaciones Marinas (CSIC), Eduardo Cabello 6, 36208 Vigo, Spain \\ ${ }^{2}$ Departamento de Biología Animal, Instituto Cavanilles de Biodiversidad y Biología Evolutiva, Universitat de València, \\ Burjassot, 46071 Valencia, Spain \\ ${ }^{3}$ Centro Tecnológico el Mar, Fundación CETMAR, Eduardo Cabello s/n, 36208 Vigo, Spain
}

\begin{abstract}
Cystacanths of the acanthocephalan Bolbosoma balaenae (Gmelin, 1790) were found encapsulated in the cephalothorax of the euphausiid Nyctiphanes couchii (Bell, 1853) from temperate waters in the NE Atlantic Ocean. Euphausiids were caught in locations outside the Ría de Vigo in Galicia, NW Spain, and prevalence of infection was up to $0.1 \%$. The parasite was identified by morphological characters. Cystacanths were $8.09 \pm 2.25 \mathrm{~mm}$ total length (mean $\pm \mathrm{SD}$ ) and had proboscises that consisted of 22 to 24 longitudinal rows of hooks, each of which had 8 or 9 hooks per row including 2 or 3 rootless ones in the proboscis base and 1 field of small hooks in the prebulbar part. Phylogenetic analyses of $18 \mathrm{~S}$ rDNA and cytocrome $c$ oxidase subunit I revealed a close relationship with other taxa of the family Polymorphidae (Meyer, 1931). The results extend northwards ot the known distribution of $B$. balaenae. Taxonomic affiliation of parasites and trophic ecology in the sampling area suggest that $N$. couchii is the intermediate host for $B$. balenae, and we suggest that the whales Balaenoptera physalus (Linnaeus, 1758) and B. acutorostrata (Lacepède, 1804) are its definitive hosts. This life cycle is probably completed with or without paratenic hosts.
\end{abstract}

KEY WORDS: Acanthocephala $\cdot$ Cystacanths $\cdot$ Bolbosoma balaenae $\cdot$ Zooplankton $\cdot$ Nyctiphanes couchii $\cdot$ NE Atlantic

Resale or republication not permitted without written consent of the publisher

\section{INTRODUCTION}

The most frequent parasites in marine zooplankton appear to be protists hosted by copepods (Skovgaard \& Saiz 2006). However, there are other groups of parasites, mostly platyhelminths, nematodes and acanthocephalans, which are also common and play a major part in both host life cycles and ecosystem food webs (Marcogliese 1995, 2002, 2004). Among zooplankton communities, euphausiids play an important role as intermediate hosts in the pelagic realm (Marcogliese 1995). They are able to attain massive biomasses and can form vast and dense swarms occupying one of the lowest trophic levels. Additionally they can be used by different types of parasites to reach their definitive host (Mauchline 1980, 1984, Marcogliese 2002).

Nyctiphanes couchii (Bell, 1853) is the most abundant euphausiid in European Atlantic waters and occurs very close to the European continental shelf. Locations where they are most abundant are near the Spanish coast, the Celtic Sea, the coasts of Ireland, Scotland and northeastern England and the entrance to the Skagerrak (Lindley 1977). In the NE Atlantic Ocean it is one of the main prey items for different cephalopods and fish species, which in turn become 
part of the diet of other vertebrates that serve as definitive hosts for a number of parasites. In addition, euphausiids are also a sizeable ingredient of the diet of some marine mammals (Raga et al. 2009). Despite the fact that parasites have great ecological importance, their recruitment (especially for acanthocephalans) in the lower levels of the food web and the role that they play is poorly understood.

Adult polymorphid acanthocephalans are intestinal parasites of marine mammals, fish-eating birds and waterfowl. Bolbosoma (Porta, 1908) and Corynosoma (Lühe, 1904) are two of the main genera of intestinal parasites that infect marine mammals (Aznar et al. 2006). The life cycle of Bolbosoma species is thought to involve pelagic marine zooplankton, especially pelagic euphausiids and copepods, as an intermediate host (Hoberg et al. 1993) and different species of fish as paratenic (transport) hosts (Raga et al. 2009). The juvenile forms of acanthocephalans are cystacanths, which are morphologically similar to the mature worms but differ from them in the size of the trunk and the degree of development of the sexual organs (Zdzitowiecki 1991, Hoberg et al. 1993). Moreover, these juvenile forms are widely considered to be the infective stage for definitive hosts. These cystacanths appear contracted with an introverted proboscis and neck inside cysts of the intermediate and paratenic hosts. The genus Bolbosoma, established for Acanthocephala from whales, contains 15 species (Amin 1985) and has a worldwide distribution (Measures 1992). Despite this, no previous data on the presence of $B$. balaenae cystacanths in euphausiids from the NE Atlantic Ocean are available. With the exception of Shimazu (1975) and Tsimbalyuk (1980), Bolbosoma has not been reported in euphausiids. Shimazu (1975) described the larvae of $B$. caenoforme (Heitz, 1920) from Thyssanoessa longipes (Brandt, 1851) and T. raschi (Sars, 1864) in the North Pacific Ocean. On the other hand, Tsimbalyuk (1980) found Bolbosoma sp. infecting Thyssanoessa sp. Recently Gómez-Gutiérrez et al. (2010) reported 3 Polymorphidae larval stages of Nyctiphanes simplex (Hansen, 1911) (probably Bolbosoma or Corynosoma) off the northwestern coast of Mexico.

Considering the background of the identification of parasites in the meso- zooplankton communities from the NE Atlantic Ocean, the aims of this paper are to (1) undertake the taxonomic and molecular diagnosis of cystacanths of Bolbosoma balaenae found in communities of $\mathrm{Nyc}$ tiphanes couchii, thereby ascertaining the role of krill in the life cycle of acanthocephalan parasites from northwest of the Iberian Peninsula, (2) provide data on the occurrence of cystacanths of $B$. balaenae in the $N$. couchii population and (3) explore the potential life cycle strategies for these cystacanths to reach their definitive host.

\section{MATERIALS AND METHODS}

\section{Collection and processing of larvae}

The zooplankton sample was collected off the coast of Ría de Vigo in Galician waters, NW Iberian Peninsula, in 1 tow of length 1 nautical mile (from $42.21^{\circ} \mathrm{N}, 09^{\circ} \mathrm{W}$ to $42.23^{\circ} \mathrm{N}, 09^{\circ} \mathrm{W}$ ) (Fig. 1) with the RV 'Mytilus' in July 2008. The sample was collected by double oblique towing, using a $750 \mathrm{~mm}$ diameter bongo net with $375 \mu \mathrm{m}$ mesh size. At a ship speed of 2 knots, the bongo net was first lowered and stabilized near the bottom for a period of $15 \mathrm{~min}$, then hauled to the surface at $0.5 \mathrm{~m}^{-1}$. The bongo net was equipped with a current meter, which allowed the volume of water filtered during the haul to be calculated, thus permitting zooplankton abundance (as

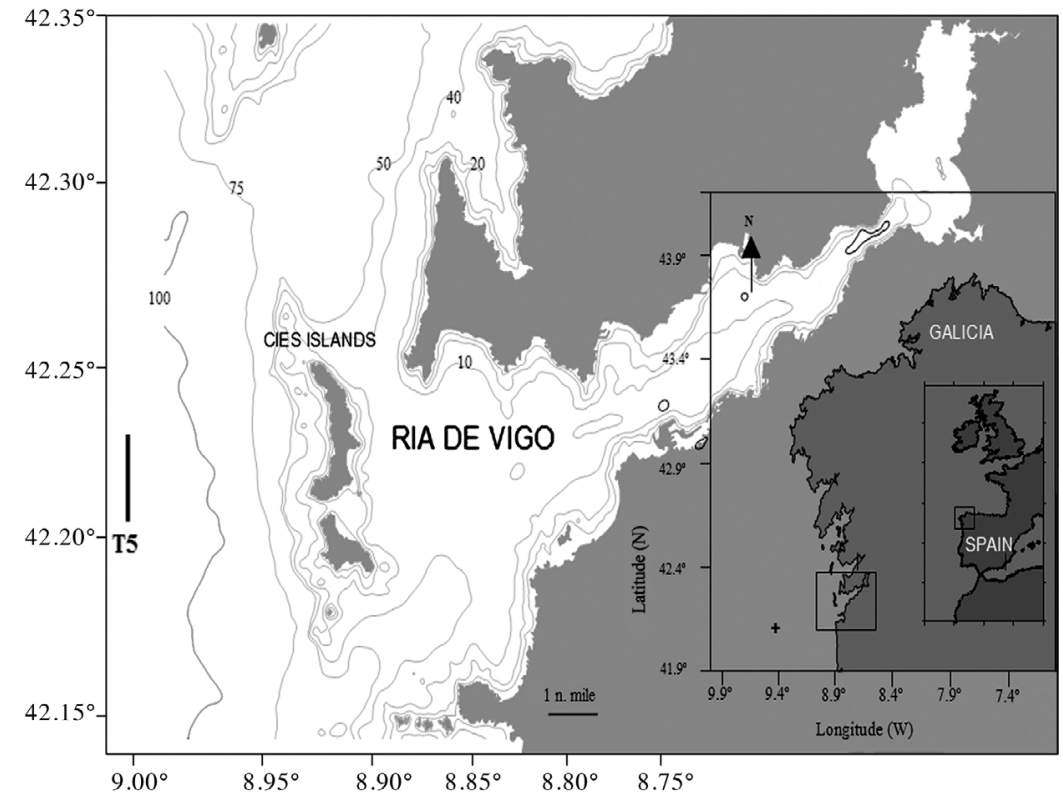

Fig. 1. Sampling transect (T5) off the Ría de Vigo in Galician waters, NE Atlantic 
no. organisms $\mathrm{m}^{-3}$ ) to be estimated. The sample was filtered with a $500 \mu \mathrm{m}$ mesh sieve and fixed onboard with $100 \%$ ethanol. In the laboratory samples were transferred to $70 \%$ ethanol and stored at $-20^{\circ} \mathrm{C}$.

The abundance of the different zooplankton taxa was calculated after counting a subsample obtained from a Folsom splitter (Omori \& Ikeda 1984). Organisms were identified to the lowest possible taxonomic level. Species diversity was calculated by using the Shannon-Wiener and Species Evenness Indices (Omori \& Ikeda 1984, Guisande et al. 2006). The number of euphausiids was estimated by the method of calculating precise replica (Andrew \& Mapstone 1987).

All the zooplankton components of the sample were examined for acanthocephalans with a stereomicroscope $(20 \times)$. When cystacanths were found, they were extracted from the host by dissection. Cystacanths were analyzed by using morphological methods. The morphological characters used for identification followed Delyamure (1955), Petrochenko (1956, 1958), Yamaguti (1963) and Zdzitowiecki (1991). The most important diagnostic characters for generic and specific assignation of species within Polymorphidae are the proboscis armature and the pattern of trunk spination, particularly of the anterior trunk (Zdzitowiecki 1991, Aznar et al. 2006 and references therein). Since the proboscis, the neck and part of the anterior trunk were introverted in all specimens, we cut the trunk posterior to the proboscis receptacle and dissected it to evert the proboscis and the anterior trunk. This body part was dissected and cleared with lactophenol to improve the visibility of structures. The rest of the body was cleared before DNA extraction. We cleared them by using different concentrations of glycerine and $70 \%$ ethanol in order to observe the degree of sexual development. The sample was initially washed in a clearing solution that consisted of 1 part pure glycerine and 3 parts $70 \%$ ethanol for $5 \mathrm{~min}$. For the second wash we used equal volumes of glycerine and $70 \%$ ethanol for $5 \mathrm{~min}$. For the third wash we used 3 parts glycerine and 1 part $70 \%$ ethanol for $10 \mathrm{~min}$, and the final wash contained $100 \%$ glycerine. This method allowed us to extract DNA from the body because the organisms were not destroyed. The following measurements were recorded: body length and width, foretrunk width (the typical bulb of Bolbosoma, see Amin \& Margolis 1998) and length of receptacle and proboscis. When possible, the number of rows of hooks and number of hooks per row were counted, and hooks were measured.

Prevalence and intensity were estimated as described by Bush et al. (1997). The CI for prevalence was calculated by the method described by Agresti \& Coull (1998) using an R macro developed by S. DoraiRaj (http://rss.acs.unt.edu/Rdoc/library/binom/html/ binom.confint.html, accessed 13 October 2011). Comparisons of prevalences were performed by using Fisher's exact tests (Rózsa et al. 2000).

\section{Genomic DNA extraction and PCR amplification}

Genomic DNA was isolated by using Qiagen DNeasy $^{\mathrm{TM}}$ Tissue Kit according to manufacturer's instructions. DNA quality and quantity was checked in a spectrophotometer (ND-1000, Nanodrop Technologies) and in $1 \%$ agarose gel. The primers LCO1490 (5-GGT CAA CAA ATC ATA AAG ATA TTG G-3 ) and HCO2198 (5-TAA ACT TCA GGG TGA CCA AAA AAT CA-3 ) (Folmer et al. 1994) were used to amplify approximately $700 \mathrm{bp}$ of the cytochrome oxidase $c$ subunit I (COI), and the primers 18SU467F (5-ATC CAA GGA AGG CAG CAG GC-3) and 18SL1310R (5-CTC CAC CAA CTA AGA ACG GC-3 ) (Suzuki et al. 2008) were employed to amplify approximately $900 \mathrm{bp}$ of the small 109 subunit (18S) ribosomal RNA gene.

PCR reactions were performed in a total volume of $25 \mu \mathrm{l}$ containing $1 \mu \mathrm{l}$ of genomic DNA (150 to $200 \mathrm{ng}$ ), PCR buffer at $1 \times$ concentration, $1.5 \mathrm{mM} \mathrm{MgCl}_{2}$, $0.2 \mathrm{mM}$ nucleotides (Roche Applied Science), $0.3 \mu \mathrm{M}$ primers and 0.625 U Taq DNA polymerase (Roche Applied Science). The cycling protocol for the COI gene was 2 min at $94^{\circ} \mathrm{C}, 35$ cycles with $30 \mathrm{~s}$ at $94^{\circ} \mathrm{C}$, $30 \mathrm{~s}$ at $50^{\circ} \mathrm{C}$ and $1 \mathrm{~min}$ at $72^{\circ} \mathrm{C}$, followed by $7 \mathrm{~min}$ at $72^{\circ} \mathrm{C}$. The cycling protocol for the $18 \mathrm{~S}$ rRNA gene was 2 min at $94^{\circ} \mathrm{C}$, 35 cycles with $30 \mathrm{~s}$ at $94^{\circ} \mathrm{C}, 1 \mathrm{~min}$ at $55^{\circ} \mathrm{C}$ and $2 \min$ at $72^{\circ} \mathrm{C}$, followed by $7 \mathrm{~min}$ at $72^{\circ} \mathrm{C}$. All PCRs were carried out in a TGradient thermocycler (Biometra) and a negative control (no DNA) was included for each set of PCR reactions. PCR products were separated on a $2 \%$ agarose (in $1 \times$ Trisacetic EDTA buffer) gel, stained with ethidium bromide and scanned in a GelDoc XR documentation system (Bio-Rad Laboratories).

\section{DNA sequencing and phylogenetic analysis}

The positive PCR products were cleaned for sequencing by using ExoSAP-IT ${ }^{\circledR}$ (USB) as supplied by the manufacturer. Sequencing was performed by Secugen (Madrid, Spain). The chromatograms were analyzed with ChromasPro v. 1.41 (Technelysium). To complete the partial sequence of the $18 \mathrm{~S}$ rDNA 
gene, the specific primer Bolbo-F1 (5-CTA TCG CCA ACG CTT TAT CT-3 ) was designed by using the program Primer-3 (Rozen \& Skaletsky 2000). Sequences were subject to basic local alignment search tool (BLAST) analyses with BLASTn against available sequences from GenBank, through web servers of the National Center for Biotechnology Information (USA). For phylogenetic analyses the sequences obtained were aligned with other acanthocephalan sequences available on GenBank. Taxa used for $18 \mathrm{~S}$ rDNA and COI analyses are listed in Table 1; the rotifer Rotaria rotatoria was used as the outgroup. Alignment was accomplished by using the Clustal W algorithm in MEGA v. 3.1 software (Kumar et al. 2004) with settings at defaults: gap opening/gap extension penalties $=15 / 6.66$ for both pairwise and

Table 1. Species and GenBank accession number of taxa used for (a) 18S rDNA and (b) COI analyses

\begin{tabular}{|c|c|}
\hline Taxon and authority & GenBank no. \\
\hline \multicolumn{2}{|l|}{ (a) 18S rDNA analysis } \\
\hline $\begin{array}{l}\text { Acanthocephaloides propinquus } \\
\text { (Dujardin, 1845) }\end{array}$ & AY830149 \\
\hline Andracantha gravida (Alegret, 1941) & EU267802 \\
\hline Corynosoma magdaleni (Montreuil, 1958) & EU267803 \\
\hline Corynosoma strumosum (Rudolphi, 1802) & EU267804 \\
\hline Echinorhynchus gadi (Zoega, 1776) & AY218123 \\
\hline $\begin{array}{l}\text { Gorgorhynchoides bullocki } \\
\text { (Cable \& Mafarachisi, 1970) }\end{array}$ & AY830154 \\
\hline $\begin{array}{l}\text { Hexaglandula corynosoma } \\
\text { (Travassos, 1915) }\end{array}$ & EU267808 \\
\hline Ibirhynchus dimorpha (Schmidt, 1973) & GQ981436 \\
\hline Pararhadinorhynchus sp. & HM545903 \\
\hline Polymorphus minutus (Goeze, 1782) & EU267806 \\
\hline Profilicollis botulus (Van Cleave, 1916 ) & EU267805 \\
\hline $\begin{array}{l}\text { Pseudocorynosoma constrictum } \\
\text { (Van Cleave, 1918) }\end{array}$ & EU267800 \\
\hline Rhadinorhynchus sp. & AY062433 \\
\hline Southwellina hispida (Van Cleave, 1925) & EU267807 \\
\hline $\begin{array}{l}\text { Transvena annulospinosa } \\
\text { (Pichelin \& Cribb, 2001) }\end{array}$ & AY830153 \\
\hline Outgroup: Rotaria rotatoria (Pallas, 1766) & AY218121 \\
\hline \multicolumn{2}{|l|}{ (b) COI analysis } \\
\hline Andracantha gravida & EU267822 \\
\hline Arhythmorhynchus frassoni (Molin, 1858) & EU189484 \\
\hline Corynosoma strumosum & EF467871 \\
\hline Echinorhynchus gadi & AY218095 \\
\hline Hexaglandula corynosoma & EU189488 \\
\hline Ibirhynchus dimorpha & GQ981438 \\
\hline $\begin{array}{l}\text { Polymorphus brevis (Van Cleave, 1916) } \\
\text { Travassos, } 1926\end{array}$ & EF467861 \\
\hline Profilicollis botulus & EF467862 \\
\hline $\begin{array}{l}\text { Pseudocorynosoma anatarium } \\
\text { (Van Cleave, 1945) }\end{array}$ & EU267821 \\
\hline Rhadinorhynchus sp. & DQ089712 \\
\hline Southwellina hispida & FJ824189 \\
\hline Transvena annulospinosa & DQ089711 \\
\hline Outgroup: Rotaria rotatoria & EU499879 \\
\hline
\end{tabular}

multiple alignments, and with transitions weighted at 0.5 . Maximum parsimony analysis was conducted by using the close neighbour interchange (CNI) heuristic option with initial trees by random addition of 1000 replicates, a search level of 1 and bootstrap values calculated over 100 replicates. Minimum evolution analysis was performed by using the Nucleotide Maximum Composite Likelihood model, the CNI heuristic option with a search level of 2, and bootstrap values were calculated over 1000 replicates.

Nucleotide sequence data reported in this paper are available in the GenBank under the Accession No. JQ040303-6.

Table 2. Zooplankton groups represented in the plankton sample obtained off the coast of Ría de Vigo, Galicia, Spain. $\mathrm{n}=$ number of individuals; $A=$ Abundance $\left(\mathrm{n} \mathrm{m}^{-3}\right) ; \%=$ percent composition of selected zooplankton categories. Total volume filtered in the tow was $410.37 \mathrm{~m}^{3}$

\begin{tabular}{|c|c|c|c|}
\hline Taxon and authority & $\mathrm{n}$ & $A$ & $\%$ \\
\hline \multicolumn{4}{|l|}{ Amphipoda } \\
\hline $\begin{array}{l}\text { Gammaridea } \\
\text { (Latreille, 1802) }\end{array}$ & 85 & 0.21 & 0.03 \\
\hline Brachyura zoeae & 2462 & 6.00 & 0.78 \\
\hline \multicolumn{4}{|l|}{ Copepoda } \\
\hline $\begin{array}{l}\text { Acartia clausii } \\
\text { (Giesbrecht, 1889) }\end{array}$ & 7421 & 18.08 & 2.34 \\
\hline $\begin{array}{l}\text { Calanoides carinatus } \\
\text { (Kroyer, 1849) }\end{array}$ & 72258 & 176.08 & 22.78 \\
\hline $\begin{array}{l}\text { Calanus helgolandicus } \\
\text { (Claus, 1863) }\end{array}$ & 35155 & 85.67 & 11.08 \\
\hline $\begin{array}{l}\text { Centropages chierchiae } \\
\text { (Giesbrecht, 1889) }\end{array}$ & 3966 & 9.67 & 1.25 \\
\hline $\begin{array}{l}\text { Paraeuchaeta hebes } \\
\text { (Giesbrecht, 1888) }\end{array}$ & 8637 & 21.05 & 2.72 \\
\hline \multicolumn{4}{|l|}{ Euphausia } \\
\hline $\begin{array}{l}\text { Nyctiphanes couchii } \\
\text { adults (Bell, 1853) }\end{array}$ & 69954 & 170.47 & 22.05 \\
\hline N. couchii calyptopis & 34432 & 88.78 & 11.49 \\
\hline N. couchii furcilia & 49387 & 120.35 & 15.57 \\
\hline Fish larvae & 511 & 1.25 & 0.16 \\
\hline Mysidacea & 1918 & 4.68 & 0.61 \\
\hline \multicolumn{4}{|l|}{ Cephalopoda } \\
\hline $\begin{array}{l}\text { Sepiola atlantica } \\
\text { (Orbigny, 1839) }\end{array}$ & 7 & 0.02 & 0.0022 \\
\hline Ophiuroidea larvae & 511 & 1.25 & 0.16 \\
\hline Paguridae megalopa & 479 & 1.17 & 0.15 \\
\hline Polychaeta larvae & 5 & 0.01 & 0.0013 \\
\hline Siphonophora & 1535 & 3.74 & 0.48 \\
\hline \multicolumn{4}{|l|}{ Stomatopoda } \\
\hline $\begin{array}{l}\text { Meiosquilla desmaresti } \\
\text { (Risso, 1816) }\end{array}$ & 479 & 1.17 & 0.15 \\
\hline Thaliacea & 21175 & 51.60 & 6.68 \\
\hline Total & 317174 & 772.94 & 100 \\
\hline Shannon-Wiener index $(H)$ & \multicolumn{3}{|c|}{1.555} \\
\hline Species Evenness index & \multicolumn{3}{|c|}{0.149} \\
\hline
\end{tabular}




\section{RESULTS}

The composition, total abundance and density of taxa collected in the zooplankton samples, as well as the Shannon-Wiener Index and Species Evenness Index values for the entire assemblage, are shown in Table 2. The most abundant taxon was Nyctiphanes couchii (Euphausiacea) which contributed $~ 49.09 \%$ to the total zooplankton community. Adults of this species made up $\sim 22.05 \%$ of the total sample, whereas furcilia and calyptopis larvae contributed $\sim 15.57$ and $\sim 11.49 \%$, respectively. Copepods contributed $\sim 41.68 \%$ of the sample, in which Calanoides carinatus were the most abundant species of this group ( $22.78 \%)$, followed by Calanus helgolandicus at $11.08 \%$. Thaliacea was also relatively abundant and contributed $\sim 6.68 \%$. The remaining zooplanktonic taxa contributed just $\sim 2.52 \%$ (Table 2 ).

A total of 70 uncoloured cystacanths putatively identified as belonging to the family Polymorphidae were removed from the thorax of adult individuals of Nyctiphanes couchii (Fig. 2A). All cystacanths had the neck and proboscis invaginated within the foretrunk and the proboscis receptacle, respectively. After dissection, diagnostic details for a specific assignation were revealed, and all specimens were identified as Bolbosoma balaenae. No evidence of genital development was observed in any specimen. A brief morphological description follows.

The cystacanth body was cylindrical (length: $8.09 \pm$ $2.58 \mathrm{~mm}$ [mean $\pm \mathrm{SD}], \mathrm{n}=60$; width at middle length: $0.41 \pm 0.08 \mathrm{~mm}, \mathrm{n}=47$ ), and had a funnel-shaped bulb (width: $0.68 \pm 0.13 \mathrm{~mm}, \mathrm{n}=59$ ) at the foretrunk (Fig. 2B), with a wide apex and narrow base (Fig. 2C). A somatic armature was present, and the single field of trunk spines was restricted to the prebulbar part or the foretrunk and composed of 4 to 6 irregular circles of small spines adjacent to the neck (no. of specimens observed $=38$ ). The bulb was unarmed. The proboscis was cylindrical (length: 0.69
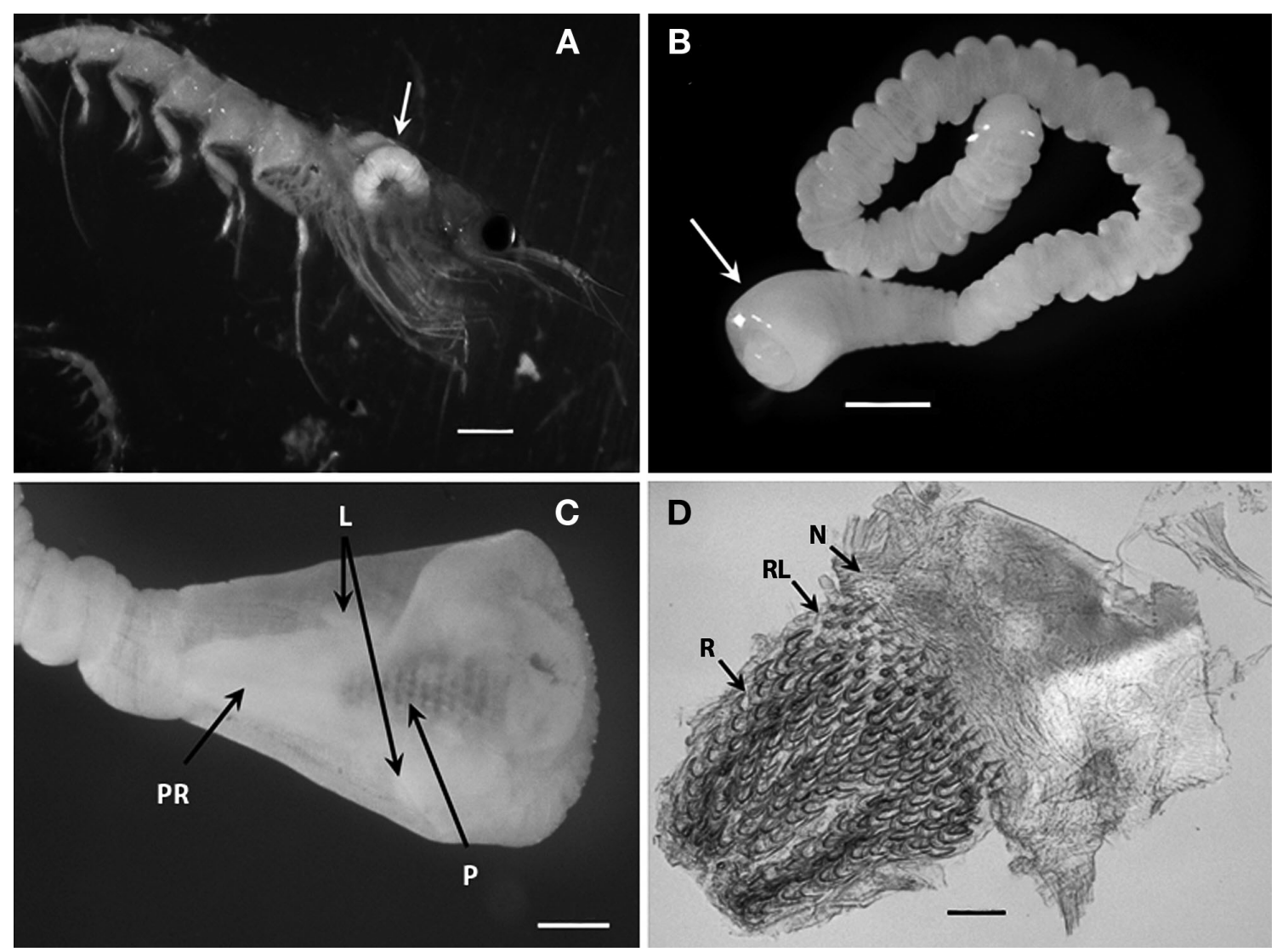

Fig. 2. Bolbosoma balaenae. (A) Cystacanth (arrow) inside the cephalothorax of Nyctiphanes couchii. Scale bar = 1 mm. (B) General view of the cystacanth. Arrow: the bulb characteristic of Bolbosoma. Scale bar $=500 \mu \mathrm{m}$. (C) Detail of the anterior part of the body showing the funnel-like-shaped bulb that contains the proboscis (P), its receptacle (PR) and lemniscis (L). Scale bar $=200 \mu \mathrm{m}$. (D) General view of the proboscis after dissection of the cystacanth showing the neck (N), rootless hooks (RL) and hooks with roots (R). Scale bar $=100 \mu \mathrm{m}$ 
$\pm 0.48 \mathrm{~mm}, \mathrm{n}=45$; width: $0.15 \pm$ $0.08 \mathrm{~mm}, \mathrm{n}=41$ ) and had 22 to 24 rows of hooks with 8 to 9 hooks per row, 6 with roots and 2 to 3 rootless (30 specimens observed) (Fig. 2D). Hook (H) lengths (in $\mu \mathrm{m}$ ) were as follows: $\mathrm{H} 1$ $(39.9 \pm 7.8, \mathrm{n}=29) ; \mathrm{H} 2(44.3 \pm 8.1, \mathrm{n}=$ 29); H3 (55.2 $\pm 11.4, \mathrm{n}=27) ; \mathrm{H} 4(59.2 \pm$ $7.3, \mathrm{n}=26) ; \mathrm{H} 5(61.1 \pm 6.1, \mathrm{n}=25) ; \mathrm{H} 6$ $(63.8 \pm 6.0, \mathrm{n}=25) ; \mathrm{H} 7(67.7 \pm 9.2, \mathrm{n}=$ 26); H8 (68.5 $\pm 5.9, \mathrm{n}=25)$; H9 (66.2 \pm $0.2, \mathrm{n}=2$ ). Voucher specimens were deposited at the Museo do Mar de Galicia, Vigo, Spain, with the accession number MDMG8012011.

The mean prevalence (95\% CI) of Bolbosoma balaenae in Nyctiphanes couchii was $0.045 \%$ (0.035 to $0.057 \%$ ). Considering only adults of $N$. couchii, the prevalence was $0.100 \%$ (0.079 to $0.127 \%$ ). All host individuals harboured single specimens of $B$. balaenae. A comparison of prevalence between $N$. couchii and arthropod taxa in the zooplankton sample with at least 1000 individuals is shown in Table 3. Only 2 copepod species had a significantly lower prevalence than that of the total sample of $N$. couchii, but all copepod species had significantly lower prevalence than that of $N$. couchii when only adults of the latter species were considered (Table 3).

\section{Molecular characterization}

The amplified and sequenced 18S rDNA and COI regions of the acanthocephalans were 885 and $512 \mathrm{bp}$ in length, respectively. The $\mathrm{G}+\mathrm{C}$ contents of the sequenced genes were $48.5 \%$ for $18 \mathrm{~S}$ rDNA and $36.4 \%$ for COI. Submission to the BLAST server showed that the most similar sequences in GenBank were the 18S rDNA of Corynosoma strumosum, C. magdaleni, C. enhydri (Morozov, 1940) and Andracantha gravida with identity values of $99 \%$, and the COI of C. strumosum with an identity value of $81 \%$. Alignment of sequences showed that 490 sites (59\%) were conserved, 333 (40.1\%) were
Table 3. Results of Fisher's exact tests that compare the prevalence of the acanthocephalan Bolbosoma balaenae in the total sample and the sample of adults only of the euphausiid Nyctiphanes couchii with that in other arthropod taxa collected in samples of zooplankton caught off Ría de Vigo, Galicia, Spain. Only taxa with $\geq 1000$ individuals are included. Brachyura zoeae were excluded because their small size precluded infections with $B$. balaenae (see also Table 2). $\mathrm{n}=$ number of individuals

\begin{tabular}{|c|c|c|c|c|}
\hline \multirow[t]{2}{*}{ Taxon } & \multirow[t]{2}{*}{$\mathrm{n}$} & \multirow{2}{*}{$\begin{array}{c}\text { Prevalence (\%) } \\
\quad(95 \% \mathrm{CI})\end{array}$} & \multicolumn{2}{|c|}{ p-value ( $N$. couchii) } \\
\hline & & & Total & Adult \\
\hline \multicolumn{5}{|l|}{ Euphausiacea } \\
\hline N. couchii & 155773 & $0.04(0.03-0.06)$ & & \\
\hline \multicolumn{5}{|l|}{ Copepoda } \\
\hline Acartia clausii & 7421 & $0(0-0.04)$ & 0.078 & 0.002 \\
\hline Calanoides carinatus & 72258 & $0(0-0.00)$ & & \\
\hline Calanus helgolandicus & 35155 & $0(0-0.00)$ & $<0.001$ & $<0.001$ \\
\hline Centropages chierchiae & 3996 & $0(0-0.08)$ & $<0.001$ & $<0.001$ \\
\hline Paraeuchaeta hebes & 8637 & $0(0-0.03)$ & 0.053 & $<0.001$ \\
\hline Paraeuchaeta sp. & 4797 & $0(0-0.06)$ & 0.277 & 0.023 \\
\hline Mysidacea sp. & 1918 & $0(0-0.16)$ & 1.000 & 0.268 \\
\hline
\end{tabular}
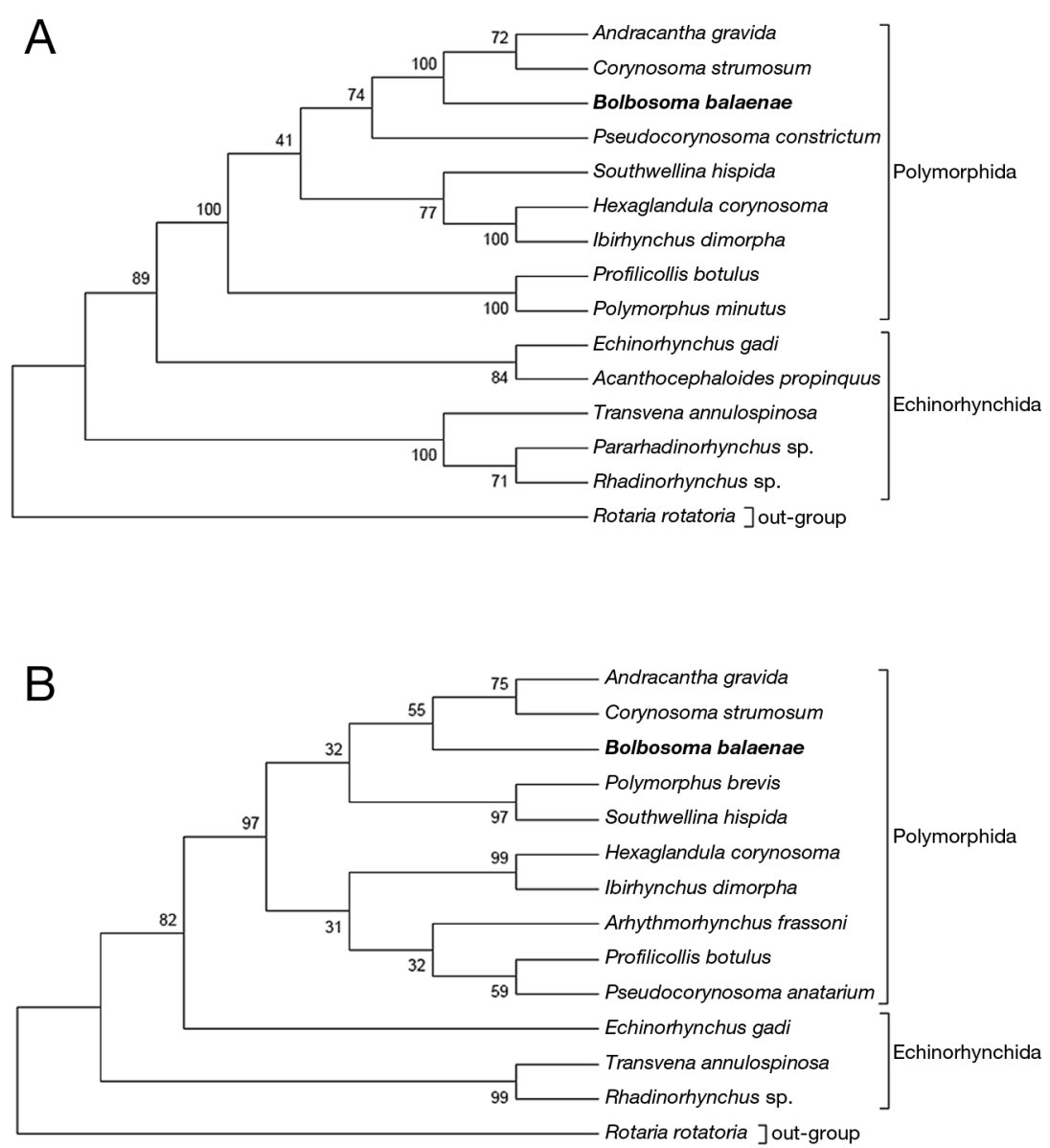

Fig. 3. Bolbosoma balaenae. Phylogenetic relationship among acanthocephalan sequences inferred by the minimum evolution algorithm within MEGA 4.1. (A) Analysis of $18 \mathrm{~S}$ rDNA sequences. (B) Analysis of COI sequences. Numbers indicate the bootstrap confidence values of 10000 replicates 
variable, $193(23.2 \%)$ were parsimony informative and $(16.7 \%)$ were singleton for $18 \mathrm{~S}$ rDNA. Of the COI sites, $150(30.8 \%)$ were conserved, $(67.9 \%)$ were variable, $219(45.0 \%)$ were parsimony informative and 30 $(17.4 \%)$ were singleton. Phylogenetic analyses using the minimum evolution (ME) and minimum parsimony (MP) methods yielded a similar tree topology, placing the species within the Polymorphidae. Phylogenetic analyses of the 18S rDNA revealed a close relationship to the sequences of C. strumosum and A. gravida, with bootstrap values of $100 \%$ for ME analysis (not shown) and $96 \%$ for MP analysis (Fig. 3). For COI phylogenetic analyses, a similar dendrogram was obtained but it was supported with low bootstrap values. The trees also showed that the Polymorphidae form a monophyletic group, which is supported by high bootstrap values (>95\%).

\section{DISCUSSION}

Within the Polymorphidae, the main diagnostic characters to identify taxa are the number and arrangement of proboscis hooks and the patterns of trunk armature (Schmidt 1973, Amin 1982, Aznar et al. 2006). For identification purposes, one advantage of these characters is that they are already visible at the cystacanth stage and remain unmodified during the adult development (Van Cleave 1952). This is the reason why some Bolbosoma species currently considered as valid have been described from cystacanths alone, e.g. B. caenoforme and B. heteracanthis (see Petrochenko 1958). Amin (1985) and Golvan (1994) listed 14 valid species within the genus Bolbosoma. Twelve species are common to both classification schemes, i.e. B. balaenae, B. bobrovoi (Krotov \& Delyamure, 1952), B. brevicolle (Malm, 1867), B. caenoforme (Heitz, 1920), B. capitatum (Linstow, 1880), B. hamiltoni (Baylis, 1929), B. heteracanthis (Heitz, 1917), B. nipponicum (Yamaguti, 1939), B. physeteris (Gubanov, 1952), B. scomberomori (Wang, 1980), B. tuberculata (Skrjabin, 1970) and B. vasculosum (Rudolphi, 1819). However, Amin (1985) considered B. thunni (Harada, 1935) as a valid species whereas Golvan (1994) considered that it could be synonymous with $B$. vasculosum, as did more recent authors (Costa et al. 2000). Amin (1985) also considered 2 subspecies within B. turbinella (Diesing, 1851), i.e. B. turbinella turbinella (Diesing, 1851) and B. turbinella australis (Skrjabin, 1972). Golvan (1994), however, regarded these subspecies as separate species. Later, Amin \& Margolis (1998) synonymized $B$. capitatum and B. physeteris.
Regardless of these slight differences between classification schemes, $B$. balaenae is the only species of Bolbosoma that has a single field of trunk spines restricted to the prebulbar foretrunk; in the remaining species, spines cover the bulb to a variable extent (Meyer 1933, Van Cleave 1953, Petrochenko 1958, Zdzitowiecki 1991, Measures 1992, Amin \& Margolis 1998, Costa et al. 2000, and references therein). The number of circles of prebulbar spines seems to vary among specimens of $B$. balaenae; Meyer (1933) mentioned 6 circles, whereas Zdzitowiecki (1991) mentioned up to 10 circles, and Van Cleave (1953) reported specimens even without spines, but he made it clear that this was a natural condition. Accordingly, the diagnostic character of somatic armature would allow a ready assignment of the cystacanths collected in this study as $B$. balaenae; the number of circles of spines observed in our sample may be considered within the range of natural variability of this species. In addition, our identification is confirmed based on the patterning of proboscis hooks. The proboscis of cystacanths collected in this study had 22 to 24 rows of hooks with 8 to 9 hooks per row, 6 with roots and 2 to 3 rootless. As far as we know, this combination of characters is shared only with previous descriptions of $B$. balaenae. Only 3 species, B. australis, B. brevicolle and B. nipponicum, have a number of rows of hooks that overlaps with that of $B$. balaenae; however, the number of hooks per row in these species is lower (range, 5 to 7 ) (see Meyer 1933, Van Cleave 1953, Petrochenko 1958, Zdzitowiecki 1991, Measures 1992, Amin \& Margolis 1998, Costa et al. 2000, and references therein).

Phylogenetic analyses shows that this species is well embedded in the family Polymorphidae and is included as a sister taxa to Corynosoma strumosum and Andracantha gravida. The phylogenetic trees herein obtained are in accordance with previous molecular and morphological phylogenetic hypotheses for acanthocephalans, which support the monophyly of this group (García-Varela et al. 2000, 2002, 2011). The absence of DNA sequences deposited in the GenBank for Bolbosoma balaenae only allows placing the species within the phylogeny of the group. However, the sequences deposited are useful as reference material for future comparisons with sequences of adults of $B$. balaenae. Interestingly, Corynosoma, Andracantha and Bolbosoma are the only genera within the Polymorphidae in which the majority or all species occur in marine hosts: Corynosoma mainly in pinnipeds, Andracantha in cormorants and Bolbosoma in cetaceans (see Hoberg et 
al. 1993, Aznar et al. 2006). The position of a member of Bolbosoma in the phylogenetic tree of the Polymorphidae opens new avenues to interpret the history of associations between these acanthocephalans and marine mammals. In particular, it is possible that the ancestor that was the origin of these forms came from a single colonization event in the marine realm. The phylogenetic trees obtained here are in accordance with the results described previously by García-Varela et al. (2000, 2002, 2011).

Apart from 3 sporadic records in oceanic odontocetes, i.e. the northern bottlenose whale Hyperoodon ampullatus (Lacépède, 1804) (see Delyamure 1955), spinner dolphins Stenella longirostris (Gray, 1828) and spotted dolphins S. attenuata (Gray, 1846) (see Dailey \& Perrin 1973), Bolbosoma balaenae has frequently been reported in at least 7 mysticetes species worldwide, including the bowhead whale Balaena mysticetus (Linnaeus, 1758), sei whale Balaenoptera borealis (Lesson, 1828), common minke whale $B$. acutorostrata (Lacépéde, 1804), fin whale $B$. physalus (Linneus, 1758), blue whale $B$. musculus (Linneaus, 1758), humpback whale Megaptera novaeangliae (Borowski, 1781) and grey whale Eschrichtius robustus (Lilljeborg, 1861) (Zdzitowiecki 1991, Dailey et al. 2000, and references therein). In the Atlantic Ocean $B$. balaenae has been found in bowhead, common minke, sei, blue and fin whales. Fin whales occupy principally a wide area between the $40^{\circ}$ and $55^{\circ} \mathrm{N}$ latitudes and migrate southward during winter months (Raga et al. 1986). It is a common species in coastal waters where upwelling events occur (Jefferson et al. 1993, Aguilar 2009). It is considered a generalist and euryphagous. In the northern hemisphere its diet is mainly composed of krill Meganyctiphanes norvegica (Sars, 1856) and Thysanoessa inermis (Kryer, 1846), other zooplanktonic crustaceans, fishes and small squids (Perrin et al. 2009), especially schooling fish such as capelin, herring, cod, sardine and mackerel (Nemoto 1959, Klumov 1963 and Mitchell 1975, all as cited in Measures 1992). Consequently this whale probably acquires $B$. balaenae from infected fish that probably serve as paratenic hosts. Reports of juvenile Bolbosoma sp. in fish implicate members of Scombridae, Scorpaenidae, Carangidae, Trichiuridae, Gempylidae, Salmonidae, Berycidae, Lophotidae, Gadidae and Belonidae (Measures 1992, www.nhm.ac.uk/research-curation/research/ projects/host-parasites/index.html).

The known geographic distribution of the euphausiid Nyctiphanes couchii includes Galician waters in NW Spain, where it is relatively abundant (Lindley 1977). As a component of the mesozooplankton, the krill is part of the diet of decapods, cephalopods (Pascual et al. 1996), fish and marine mammals (Mauchline 1980). This places in one of the lowest trophic levels, allowing the transmission of the cystacanths towards a definitive host throughout predator-prey interactions (Marcogliese 1995).

This is the first time that Bolbosoma balaenae has been found in the euphausiid Nyctiphanes couchii, which probably acts as an intermediate host. Hoberg et al. (1993) and Gómez-Gutiérrez et al. (2010) suggested that euphausiids and copepods could be the intermediate hosts of the genus Bolbosoma and Acanthocephala in general. Nevertheless, only 2 studies have reported the genus Bolbosoma in euphausiids (Shimazu 1975, Tsimbalyuk 1980). In our samples we found Bolbosoma only in adults of $N$. couchii, despite the fact that we studied a great number of copepod species and other zooplankton components. This reinforces the idea proposed by Nickol et al. (2002) in which different genera of Polymorphidae are specialized in a specific fraction of zooplankton. Consequently, it is possible that B. balaenae is specific for this species of krill (N. couchii) in the NE Atlantic Ocean.

We did not find Bolbosoma balaenae larvae in the Euphausiacea larvae (calyptopis and furcilias, which were 0.8 to $2.20 \mathrm{~mm}$ and 2.2 to $5.5 \mathrm{~mm}$ in total length, respectively), nor in the copepod species or other taxa from our sample; this fact could be due to the large size of these cystacanths $(8.09 \mathrm{~mm})$. We speculate that only adults of Nyctiphanes couchii could harbour them in their body cavity (12 to $17 \mathrm{~mm}$ length). The larger copepods in our sample were Calanus helgolandicus, Calanoides carinatus and Paraeuchaeta hebes, and none exceeded a total length of $3 \mathrm{~mm}$. The smaller ones were Acartia clausii, Centropages chierchiae and Temora longicornis (Müller O.F., 1785), whose size is always smaller than $2 \mathrm{~mm}$. Despite finding Mysidacea with a similar size to euphausiids in our sample, we did not find cystacanths inside. Probably this is due to the low numbers in our sample or because they occupy a different niche and have a different behaviour. Consequently, it seems that the smaller crustaceans cannot harbour cystacanths nor act as intermediate host for these acanthocephalans.

Additionally, none of the examined Nyctiphanes couchii showed more than one cystacanth per individual. Therefore, it seems that krill are able to harbour only one cystacanth. Nevertheless it is desirable to carry out experimental infections to validate the null hypothesis of host size as a limiting factor for infection intensity or determine whether the dilution of the pelagic realm could be that factor. It is true that 
multiple infections can reduce survival rates and perhaps we did not find more than one cystacanth in a host because these hosts died. Also, we only found cystacanths in the cephalothorax of krill, as did Shimazu (1975), Sars (1885), Lindley (1977) and GómezGutiérrez et al. (2010), who also found Polymorphidae acanthocephalans in different species of krill. On the other hand, different Polymorphidae cystacanths have been reported in crabs with frequencies of more than one individual per crab. Nickol et al. (2002) detected infections of Arhythmorhynchus (Lühe, 1911) and Hexaglandula (Petrochenko, 1950) in fiddler crabs. In that case they found a crab that harboured a maximum of 3 cystacanths while the rest of the crabs examined harboured only 1 per individual. Balboa et al. (2009) detected the same larval stage harboured by several Brachyura (Linnaeus, 1758) and Anomura (Macleay, 1838), which showed differences in the intensity of infection. Experimental infections are required to determine whether size is the limiting factor for infection intensity.

The low prevalence $(0.1 \%)$ observed in adults of Nyctiphanes couchii is usually considered a feature of an invertebrate intermediate host, especially in zooplankton communities (Marcogliese 1995). This is mainly because of the effect of dilution in the pelagic realm where finding a suitable intermediary host may be difficult. In spite of this low prevalence, most predators ingest large quantities of crustaceans and thus acquire prevalent and heavy infections (Marcogliese 1995). The information on larval acanthocephalans in euphausiid communities is very scanty and most of this information comes from studies on lake and river ecosystems where euphausiids, being marine organisms, are not found. Moreover the low prevalence is common for intermediate crustacean hosts (Uznanski \& Nickol 1980, Ashley \& Nickol 1989). Despite different ecosystem and transmission pathways, the prevalence $(0.1 \%)$ agrees with those found for different acanthocephalan genera and platyhelminthes compiled in zooplanktonic communities (Marcogliese 1995).

Although there is information on other acanthocephalan species infecting zooplanktonic groups, no data on their prevalence is available (Hubschman 1983 and Wilson \& Hubschman 1985 as cited in Marcogliese 1995, Dezfuli 1996, Bush et al. 2001, Kakizaki et al. 2003).

Owing to the high abundance of Balaenoptera physalus off the west coast of the Iberian Peninsula, we suggest that this whale could be a definitive host of Bolbosoma balaenae in this geographical region, which supplies and supports an infective population in the euphausiids. We also consider that the minke whale and other mammals could be additional suitable definitive hosts of this parasite in the NE Atlantic Ocean. However, we cannot rule out the possibility that the life cycle of $B$. balaenae could also involve pelagic fishes and cephalopods as paratenic hosts, which in turn are an important commercial resource in the area studied (http://conselleriamar. xunta.es/web/pesca/datos-producion).

Owing to the high importance of the euphausiids within the marine pelagic trophic webs, and taking into account that they are a key component, directly and/or indirectly, in the dietary habits of many cephalopods, fishes and marine mammals, we suggest that it would be interesting to undertake further studies focused on the possible interactions between the recruitment of Bolbosoma balaenae to Nyctiphanes couchii driven by the upwelling events that occur in this area of the NE Atlantic Ocean.

Acknowledgements. The authors are grateful to many colleagues for assisting them with the collection and selection of zooplankton and to all the crew of the RV 'Mytilus'. We also thank M. Cueto, F. Álvarez and J. Antonio for helping us with technical analysis. We especially thank Prof. Á. Guerra for his comments that improved the original manuscript. This research was conducted within the National Projects 'CAIBEX' (CTM-2007-66408-CO2-01), LARECO (CTM 2011-25929) and was also supported by project CGL200763221, MEC, Spain. The equipment was partially funded with FEDER Funds. M.G. was supported by a JAE-CSIC predoctoral scholarship.

\section{LITERATURE CITED}

Agresti A, Coull BA (1998) Approximate is better than 'exact' for interval estimation of binomial proportions. Am Stat 52:119-126

Aguilar A (2009) Fin whale: Balaenoptera physalus. In: Perrin WF, Thewissen HGM, Würsing B (eds) Encyclopedia of marine mammals, 2nd edn. Academic Press/Elsevier, Amsterdam, p 433-437

Amin OM (1982) Acanthocephala. In: Parker SP (ed) Synopsis and classification of living organisms, Vol 1. McGrawHill, New York, NY, p 933-940

Amin OM (1985) Classification. In: Crompton DWT, Nickol BB (eds) Biology of the Acanthocephala. Cambridge University Press, London, p 27-72

Amin OM, Margolis L (1998) Redescription of Bolbosoma capitatum (Acanthocephala: Polymorphidae) from false killer whale off Vancouver Island, with taxonomic reconsideration of the species and a synonymy of $B$. physeteris. J Helminthol Soc Wash 65:179-188

Andrew NL, Mapstone BD (1987) Sampling and the description of spatial pattern in marine ecology. Oceanogr Mar Biol Annu Rev 25:39-90

Ashley DC, Nickol BB (1989) Dynamics of the Leptorhynchoides thecatus (Acanthocephala) suprapopulation in a Great Plains reservoir. J Parasitol 75:46-54 
Aznar FJ, Pérez-Ponce de León G, Raga JA (2006) Status of Corynosoma (Acanthocephala: Polymorphidae) based on anatomical, ecological and phylogenetic evidence, with the erection of Pseudocorynosoma n. gen. J Parasitol 92: 548-564

Balboa L, Hinojosa A, Riquelme C, Rodríguez S, Bustos J, George-Nascemento M (2009) Alloxenic distribution of cystacanth of two Profilicollis species in sympatric crustacean hosts in Chile. J Parasitol 95:1205-1208

Bush AO, Lafferty KD, Lotz JM, Shostak AW (1997) Parasitology meets ecology on its own terms. Margolis et al. revisited. J Parasitol 83: 575-583

Bush AO, Fernández JC, Esch GW, Seed JR (2001) Parasitism: the diversity and ecology of animal parasites. Cambridge University Press, Cambridge

Costa G, Chubb JC, Veltkamp CJ (2000) Cystacanths of Bolbosoma vasculosum in the black scabbard fish Aphanopus carbo, oceanic horse mackerel Trachurus picturatus and common dolphin Delphinus delphis from Madeira, Portugal. J Helminthol 74:113-120

Dailey MD, Perrin WF (1973) Helminth parasites of the genus Stenella in the eastern tropical Pacific with descriptions of two new species: Mastigonema stenella gen. et sp. n. (Nematoda: Spiruroidea) and Zalophotrema pacificum sp. n. (Trematoda: Digenea). Fish Bull 71:455-471

> Dailey MD, Gullant FMD, Lowenstine LJ, Silvagni P, Howard D (2000) Prey, parasites and pathology associated with the mortality of a juvenile gray whale (Eschrichtius robustus) stranded along the northern California coast. Dis Aquat Org 42:111-117

Delyamure SL (1955) Helminthofauna of marine mammals (ecology and phylogeny). Izdatel'stvo Akademii Nauk SSSR, Moscow (English translation by the Israel Programme of Scientific Translations, 1968)

Dezfuli BS (1996) Cypria reptans (Crustacea: Ostracoda) as an intermediate host of Neoechinorhynchus rutili (Acanthocephala: Eoacanthocephala) in Italy. J Parasitol 82: 503-505

Folmer O, Black M, Hoeh W, Lutz R, Vrijenhoek R (1994) DNA primers for the amplification of mitochondrial cytochrome $C$ oxidase subunit I from diverse metazoan invertebrates. Mol Mar Biol Biotechnol 3:294-299

> García-Varela M, Pérez-Ponce de León G, de la Torre P, Cummings MP, Sarma SSS, Laclette JP (2000) Phylogenetic relationships of Acanthocephala based on analysis of $18 \mathrm{~S}$ ribosomal RNA gene sequences. J Mol Evol 50: $532-540$

> García-Varela M, Cummings MP, Pérez-Ponce de León G, Gardner SL, Laclette JP (2002) Phylogenetic analysis based on 18S ribosomal RNA gene sequences supports the existence of class Polyacanthocephala (Acanthocephala). Mol Phylogenet Evol 23:288-292

> García-Varela M, Pérez-Ponce de León G, Aznar JF, Nadler SA (2011) Erection of Ibirhynchus gen. nov. (Acanthocephala: Polymorphidae). J Parasitol 97:97-105

Golvan YJ (1994) Nomenclature of the Acanthocephala. Res Rev Parasitol 54:135-205

Gómez-Gutiérrez J, Robinson CJ, Kawaguchi S, Nicol S (2010) Parasite diversity of Nyctiphanes simplex and Nematoscelis difficilis (Crustacea: Euphausiacea) along the northwestern coast of Mexico. Dis Aquat Org 88: 249-266

Guisande C, Barreiro A, Maneiro I, Riveira I, Vergara A, Vaamonde A (2006) Tratamiento de datos. Ediciones Díaz de Santos, Madrid
Hoberg EP, Daoust PY, McBurney S (1993) Bolbosoma capitatum and Bolbosoma sp. (Acanthocephala) from sperm whales (Physeter macrocephalus) stranded on Prince Edward Island, Canada. J Helminthol Soc Wash 60: 205-210

Jefferson AT, Leatherwood S, Webber MA (1993) Marine mammals of the world. United Nations Program. FAO, Rome

> Kakizaki T, Saito T, Ohtaka A, Nagassawa K (2003) Effects of Acanthocephalus sp. (Acanthocephala: Echinorhynchidae) on the body size and reproduction of isopods (Asellus hilgendorfi). Limnology 4:43-46

Kumar S, Tamura K, Nei M (2004) MEGA3: integrated software for molecular evolutionary genetics analysis and sequence alignment. Brief Bioinform 5:150-163

Lindley JA (1977) Continuous plankton records: the distribution of the Euphausiacea (Crustacea: Malacostraca) in the North Atlantic and the North Sea, 1966-1967. J Biogeogr 4:121-133

> Marcogliese DJ (1995) The role of zooplankton in the transmission of helminth parasites to fish. Rev Fish Biol Fish 5: 336-371

> Marcogliese DJ (2002) Food webs and the transmission of parasites to marine fish. Parasitology 124:S83-S99

> Marcogliese DJ (2004) Parasites: small players with crucial roles in the ecological theatre. EcoHealth 1:151-164

> Mauchline J (1980) The biology of mysids and euphausiids. In: Blaxter JHS, Russell FS, Younge M (eds) Advances in marine biology, Book 18. Academic Press, San Diego, CA, p 373-681

Mauchline J (1984) Euphausiid, stomatopod and leptostracan crustaceans. Key and notes for the identification of the species. In: Kermack DK, Barnes RSK (eds) Synopses of the British fauna (new series, no. 30). The Linnaean Society of London and the Estuarine and Brackish-Water Science Association, London, p 1-91

Measures LN (1992) Bolbosoma turbinella (Acanthocephala) in a blue whale, Balaenoptera musculus, stranded in the St. Lawrence Estuary, Quebec. J Helminthol Soc Wash 59:206-211

Meyer A (1933) Acanthocephala. In: Dr HG Bronns, Klassen und Ordnungen des Tier-Reichs Leipzig, Akademische Verlagsgesellschaft MBH 4:1-332

Nickol BB, Heard RW Jr, Smith NF (2002) Acanthocephalans from crabs in the southeastern US, with the first intermediate hosts known for Arhythmorhynchus frassoni and Hexaglandula corynosoma. J Parasitol 88: 79-83

Omori M, Ikeda T (1984) Methods in marine zooplankton ecology. John Wiley and Sons, New York, NY

Pascual S, González AF, Arias C, Guerra A (1996) Biotic relationships of Illex condetii and Todaropsis eblanae (Cephalopoda, Ommastrephidae) in the Northeast Atlantic: evidence from parasites. Sarsia 81:265-274

Petrochenko VI (1956) Acanthocephala of domestic and wild animals, Vol 1. Isdatel'stvo Akademii Nauk SSSR, Moscow (English Translation by the Israel Program for Scientific Translations, 1971)

Petrochenko VI (1958) Acanthocephala of domestic and wild animals, Vol 2. Isdatel'stvo Akademii Nauk SSSR, Moscow (English Translation by the Israel Program for Scientific Translations, 1971)

Raga JA, Aguilar A, Fernandez JP, Carbonell E (1986) Parasitofauna de Balaenoptera physalus (L. 1758) (Cetacea: Balaenopteridae) en las costas atlánticas españolas: I. 
Sobre la presencia de Ogmogaster antarticus Johnston, 1931 (Trematoda: Notocotylidae). Rev Iber Parasitol 46: 237-241

Raga JA, Fernández M, Balbuena JA, Aznar FJ (2009) Parasites. In: Perrin WF, Thewissen HGM, Würsing B (eds) Encyclopedia of marine mammals, 2nd edn. Academic Press/Elsevier, Amsterdam, p 821-829

Rózsa L, Reiczigel J, Majoros G (2000) Quantifying parasites in samples of host. J Parasitol 86:228-232

Rozen S, Skaletsky HJ (2000) Primer3 on the WWW for general users and for biologist programmers. In: Krawetz S, Misener S (eds) Bioinformatics methods and protocols: methods in molecular biology. Humana Press, Totowa, NJ, p 365-386

Sars GO (1885) Report on the Schizopoda collected by H.M.S. Challenger during the years 1873-1876. In: Zoology, Part 37. Report of the scientific results of the voyage of H.M.S. Challenger, Vol 13, Edinburgh

Schmidt GD (1973) Resurrection of Southwellina Witenberg, 1932, with a description of Southwellina dimorpha sp. n., a key to genera in Polymorphida (Acanthocephala). J Parasitol 59:299-305

Shimazu T (1975) Some cestode and acanthocephalan larvae from euphausiid crustaceans collected in the northern North Pacific Ocean. Bull Jpn Soc Sci Fish 41: 813-821

Skovgaard A, Saiz E (2006) Seasonal occurrence and role of

Editorial responsibility: David Marcogliese,

Montreal, Quebec, Canada protistan parasites in coastal marine zooplankton. Mar Ecol Prog Ser 327:37-49

Suzuki N, Hoshino K, Murakami K, Takeyama H, Chow S (2008) Molecular diet analysis of Phyllosoma larvae of the Japanese spiny lobster Palinurus japonicus (Decapoda: Crustacea). Mar Biotechnol 10:49-55

Tsimbalyuk EM (1980) Results of an examination of the parasite fauna of planktonic organisms in Far-Eastern seas of the USSR. Voprosy parazitologii vodnykh bespozvonochnykh zhivotnykh. (Tematicheskii Sbornik). Akademiya Nauk Litovskoi SSR, Institut Zoologii i Parazitologii, Vilnyus, p 103-104 (in Russian)

> Uznanski RL, Nickol BB (1980) Parasite population regulation: lethal and sublethal effects of Lepthorhynchoides thecatus (Acanthocephala: Rhadinorhynchidae) on Hyalella azteca (Amphipoda). J Parasitol 66:121-126

> Van Cleave HJ (1952) Some host-parasite relationships of the Acanthocephala, with special reference to the organs of attachment. Exp Parasitol 1:305-330

Van Cleave HJ (1953) Acanthocephala of North American mammals. Illinois Biological Monograph 23. University of Illinois Press, Urbana, IL

Yamaguti S (1963) Systema Helminthum, Vol 5. Acanthocephala. Wiley Interscience, New York, NY

Zdzitowiecki K (1991) Antarctic Acanthocephala. In: Wägele JW, Sieg J (eds) Synopses of the Antarctic benthos, Vol 3. Koeltz Scientific Books, Koenigstein, p 1-116

Submitted: July 7, 2011; Accepted: February 22, 2012

Proofs received from author(s): May 4, 2012 